\title{
THE STRATEGIC PLANNING OF IS/IT AT PT. LINTAS GROUP
}

\author{
Hendra Maya Topani \\ Master of Management System Information Department, Binus Graduate Programs, \\ Bina Nusantara University J1 Kebun Jeruk Raya No. 27, Jakarta Barat 11530, Indonesia \\ dra_maya_topani@yahoo.com
}

\begin{abstract}
The purpose of this study is to find the requirement of Information Systems and Information Technology (IS/IT) in the development of the construction of Base Transceiver Station tower (BTS). The methodology that is used is the method of Ward and Peppard. The relevant data were extracted from interviews with the management. Questionnaires were distributed to 16 respondents, and observation was made accordingly. The results of this study are in the form of the application portfolio recommendation, proposal of the IT Division enhancement and the action time of IS/IT. The planning of IS/IT is as a guiding framework for the development of future changes at PT. Lintas Group.
\end{abstract}

Keywords: Information System, Technology Information, application portfolio, telecommunication.

\section{INTRODUCTION}

Telecommunication is a tool for public where the implementation needs the infrastructure of telecommunication tower [1]. The extensive development in the construction of Base Transceiver Station (BTS) tower, no official data of the total of BTS' towers that were constructed during this entire region in Indonesia was found. The current total of cellphones' users in Indonesia is 180 million users and the growth average is around 17 percent per year [2]. The escalation of telecommunication users makes companies improve the service and products in the construction of BTS tower.

The development of BTS is affected by the needs of telecommunication users which increase and affect the competition in searching potential area for the construction of BTS, so that the telecommunication network can be accessed and there is no signal jamming. According to Ref. [3], the excessive placement of towers without correct planning will create poor effects of the following: (1) The emergence of potential violence towards the urban land use plan. (2) The potential violence of flight operation safety area provision.

To organize in avoiding the problems of the urban land use plan, then within the regulation, Ref. [1] explains the construction and function of telecommunication tower as one of the supporting infrastructure in the telecommunication implementation have to pay attention to efficiency, environment safety, and environment aesthetics. This research gives a strategic planning of IS/IT at PT.
Lintas Group with the problem formulation regarding the implementation of IS/IT that is not appropriate with current needs and the long-term company's business goal.

The strategic formulation is an organized future steps that are intended to build vision and mission of the organization, determine strategic objectives and company's financial, as well as to design the strategy in obtaining the objectives in order to provide the best customer value. The main objective in planning information strategic is to organize computer-based system [4].

The strategic planning of company in telecommunication has played an important role to make a company develop, innovative, favorable and competitive, where they really understand the dynamic of telecommunication industry and market. In Addition, the placement of strategic resources as one of the key factors in maintaining competitive excellence, cost efficiency, attractiveness for the investors [5]. This challenge is connected with theneeds of Life Cycle Assessment in the Telecommunication is understood as an industrial process that is based to contribute towards the enhancement of environment performance from the products [6].

\section{METHOD}

The research of information strategic planning of IS/IT at PT. Lintas Group is using the method of analysis and strategy process according to Ref. [7] and is modified by the writer as the analysis on the following Figure 1. 


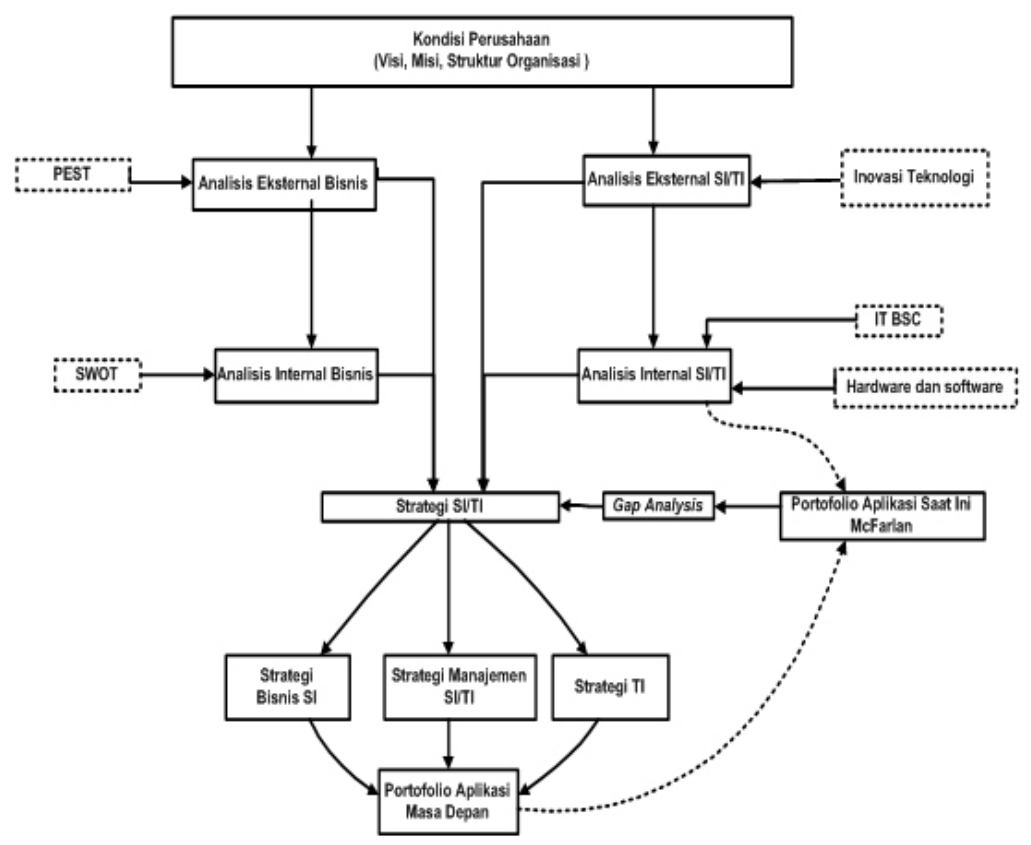

Fig. 1: The strategic process of IS/IT

Within this step, analysis is performed through 4 steps by evaluating the business and IS/ IT condition through business external to understand competition condition and business internal focuses towards the company's regulation whereas in IS/IT internal regarding infrastructure detail IS/IT and IS/ IT external regarding the analysis of the developing trend technology.

\section{Data Collection}

Primary and secondary data are needed to support analysis strengthening such as the condition of IS/IT at PT. Lintas Group, and other data. The steps is began by doing interview to some several top management, then followed by the fulfillment of questionnaires through some company's staffs, lastly by doing observation where related literature study is needed.

\section{Data Analysis}

To understand how the company's condition towards the internal environment as well as business and IS/IT external then analysis is needed towards the data that is presented using analysis tool such as PEST, ITBSC, SWOT, and GAP analysis.

\section{RESULTS AND DISCUSSION}

PT. Lintas Group focuses in the development of the construction of Base Transceiver Station tower (BTS), based on the result of the interview to determine a BTS' tower candidate, through the following steps in figure 2 .

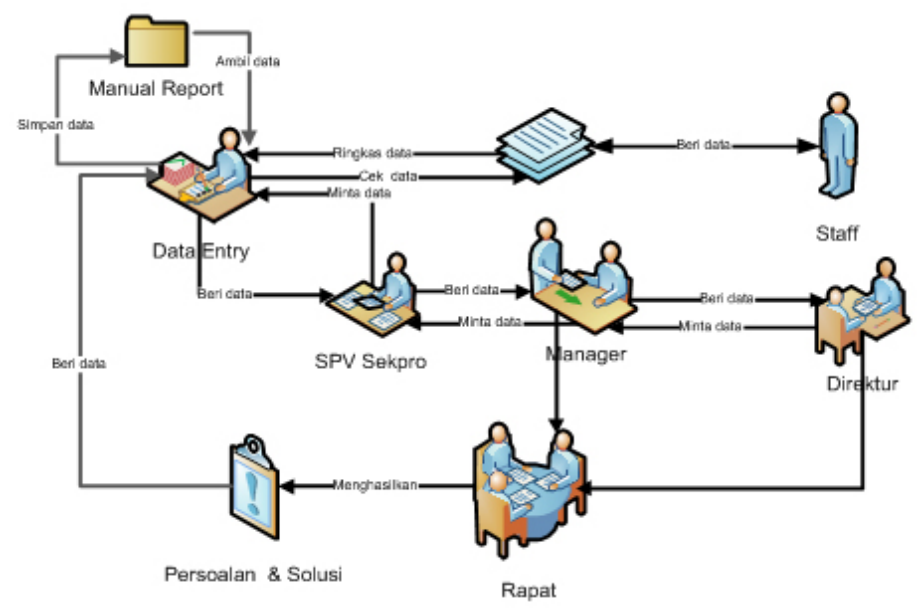

Fig. 2: The reporting process of BTS expansion 
Figure 2 explains about the development process of BTS' tower construction still encountered problem such as the lack of integration of the data processing system which is not available, therefore the impact of the said indication causes the inhibition of a decision making. Based on the problem, to support the business in a long period, strategic planning of IS/ IT at PT. Lintas Group is needed.

\begin{abstract}
Analysis
PEST Analysis

PEST analysis is an analysis towards the external power that can affect the process of business. By knowing and evaluating chances and external threat, company will be able to develop vision and mission as a correct, fundamental strategy in achieving long-term goals. The following is the result of PEST analysis at PT. Lintas Group.
\end{abstract}

Table 1: The Result Summary of PEST

\begin{tabular}{llll}
\hline \multicolumn{1}{c}{ Factor } & \multicolumn{1}{c}{ Threat } & \multicolumn{1}{c}{ Strategy } \\
\hline Politic & $\begin{array}{l}\text { 1. } \\
\text { 2. } \begin{array}{l}\text { UUD19/PER/M.KOMINFO/03/2009 } \\
\text { no.2 2008the top management has to }\end{array}\end{array}$ & $\begin{array}{l}\text { 1. } \\
\text { The top management has to address the } \\
\text { government's regulation in the demolition of } \\
\text { tower's construction } \\
\text { Cooperating with the regional government in an } \\
\text { effort to see the allowed zone of urban land use } \\
\text { plan. }\end{array}$ \\
Economy & $\begin{array}{l}\text { 1. The availability of tax collection cost either } \\
\text { legal or illegal in tower construction. } \\
\text { 2. Rupiah exchange rate is not stable }\end{array}$ & $\begin{array}{l}\text { 1. } \\
\text { Sinancial management organize the income and } \\
\text { making financial plan in every period. }\end{array}$ \\
1. $\begin{array}{l}\text { The lack of counseling is really affecting } \\
\text { towards the society's environment. }\end{array}$ & $\begin{array}{l}\text { 1. } \\
\text { Making an intensive approach to the society, } \\
\text { giving counseling in a form of social activity. }\end{array}$ \\
\hline
\end{tabular}

\section{TBC Analysis}

The measurement result from four perspectives of IT BSC shows that the performance of IT division is considered in adequate category with the average of $69 \%$ can be seen in table 2 .

Table 2 The Summary of Measurement Result of IT's Division Performance

\begin{tabular}{lcc}
\hline \multicolumn{1}{c}{ Perspective } & $\begin{array}{c}\text { Measurement } \\
\text { Result }\end{array}$ & Quality \\
\hline $\begin{array}{l}\text { Company Contribution } \\
\text { Perspective }\end{array}$ & $60.7 \%$ & Deficient \\
$\begin{array}{l}\text { Users Orientation Perspective } \\
\text { Operational Improvement }\end{array}$ & $54.1 \%$ & Very Deficient \\
$\begin{array}{l}\text { Perspective } \\
\text { Future Orientation }\end{array}$ & $60.5 \%$ & Deficient \\
$\begin{array}{l}\text { Perspective } \\
\text { Average }\end{array}$ & $67.6 \%$ & Adequate \\
\hline
\end{tabular}

Based on Table 2, it can be concluded that the performance of IT Division is based on some several perspectives: (1) Company Contribution in documentation is done systemically in every Division that develop IS which can enhance the performance in making decision based on statistic data. (2) User Orientation is done in evaluating the user's skill towards the existing system (application), and formulating the steps that will be taken to increase skill level and user's understanding. (3) Operational Improvement is done the system (application) evaluation that has already exist to know which aspect that has to be developed and which problem that exist in the system (application) and to maintain the existing network so that it can function optimally. (4) Future Orientation gives intensive training in the event of increasing the skill of the staffs.

\section{SWOT Analysis}

The result of Strength, Weakness, Opportunity, and Threat analysis of PT. Lintas Group is as following: (1) Strength - The work culture is already good, knowledge or expertise, commitment from top level management to do IS/IT utilization, quick service and the quality of products are international certified standard, maintaining good cooperative relation between working partners. (2) Weakness - The lack of marketing knowledge and obtaining accurate information is still difficult regarding the process and progress of towers, the data of regional topography's information is still cannot be processed, the existence of a material product that is not fine, the tardiness in delivering material, IS/IT has not been integrated with the central system. (3) Opportunity - The developing market, the combination of 2-3 companies or alliance, competitor that cannot fulfill the customers' demand, technology development within the design of tower, having partners with the 
class of enterprise. (4) Threat - New competitors in the same area and price competition, limited budget, competitors hold the biggest market share with the possessed technology development, rapid technological development, the devolvement of potential human resources.
The following is the internal and external factors:

Total Strength - Total Weakness $=\mathrm{X}$

$1.819-1.182=0.637(\mathrm{X})$

Total Opportunities - Total Threat $=\mathrm{Y}$

$1.955-1.055=0.9(\mathrm{Y})$

The diagram of valuation result is made by displaying the position of PT/ Lintas Group which can be seen in figure 3.

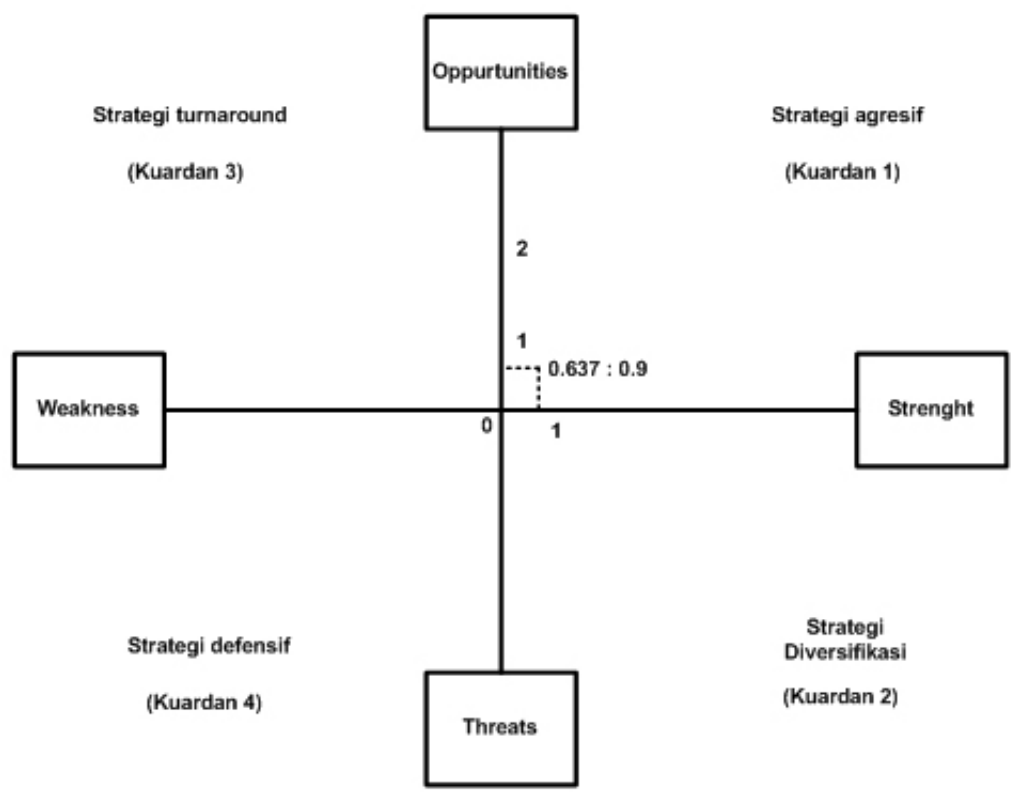

Fig. 3: SWOT Diagram

The above diagram shows that PT. Lintas Group's position is in the aggressive strategic position (quadrant 1), with the focus to minimize internal problems in seizing the better chances (market). The company has to be able to utilize the power that is possessed in order to develop business in telecommunication and utilize the existing chances, cover the weakness that happens at company as well as utilize the existing power optimally.

Strategy for PT. Lintas Group by using the matrix of SWOT is obtained at the position of SO (Strength and Opportunity) strategy where it is mapped in Table 3.

Table 3: SO Strategy

\section{SO Strategy}

1. Making the design of system application, network topology infrastructure, and increasing Human Resource's skills.

\section{IS/IT Needs}

1. The existence of infrastructure which support the integration of the whole process, system and data that is needed.

2. The availability of a system application that support the business' performance.

3. The addition in the structure of IT Division that responsible in making the planning of IS's utilization.

\section{IS/IT Support}

SIG

$\mathrm{BI}$

KMS

1. The availability of a system application that can observe the geolocation of the whole existing towers.

BI information to determine the potential location point in tower's construction.

2. The availability of statistic data regarding regional, product, and developer data in making development of BTS' tower construction. 
Based on the analysis of company's needs, the supporting application that can be developed at PT. Lintas Group to increase the performance can be seen in Table 4.
The comparative analysis from the current condition and the needs regarding the desired condition of PT. Lintas Group gives an application portfolio solution, such as SIG, KMS, BI, that are explained in Table 5 .

Table 4: Portfolio Mapping

of the Upcoming Application

\begin{tabular}{|c|c|c|c|c|}
\hline \multirow[t]{2}{*}{ Application } & \multicolumn{2}{|c|}{$\begin{array}{l}\text { Potential Contribution from IS/IT } \\
\text { to reach the goal of Business }\end{array}$} & \multicolumn{2}{|c|}{$\begin{array}{l}\text { The dependency of continuation of } \\
\text { company's activity towards IS/IT. }\end{array}$} \\
\hline & Low & High & Low & High \\
\hline SIG & & $\sqrt{ }$ & & $\sqrt{ }$ \\
\hline BI & & $\sqrt{ }$ & & $\sqrt{ }$ \\
\hline KMS & $\sqrt{ }$ & & & $\sqrt{ }$ \\
\hline
\end{tabular}

Table 5: Discrepancy Analysis

\begin{tabular}{|c|c|c|c|}
\hline Solution & Needs & Current Condition & Desired Condition \\
\hline KMS & $\begin{array}{l}\text { Knowledge enhancement of } \\
\text { staffs in solving problems, } \\
\text { increasing innovation }\end{array}$ & $\begin{array}{l}\text { 1. The unavailability of share } \\
\text { knowledge between new employees } \\
\text { and old employees. } \\
\text { 2. Employees' training that is done in } \\
\text { the present is still inadequate and } \\
\text { not continuance. } \\
\text { 3. Every knowledge is held by each } \\
\text { specific employee. } \\
\text { 4. Material resources are still in the } \\
\text { form of manual not systemically. }\end{array}$ & $\begin{array}{l}\text { 1. The availability of system that } \\
\text { can provide learning tool media } \\
\text { between each employee. } \\
\text { 2. Sharing knowledge concerning } \\
\text { new idea of telecommunication } \\
\text { between employees. } \\
\text { 3. Contributing additional information } \\
\text { as a training skill towards the } \\
\text { employees of PT. Lintas Group. }\end{array}$ \\
\hline GIS & $\begin{array}{l}\text { Monitoring and evaluating } \\
\text { the construction with regard } \\
\text { to a change of area / land } \\
\text { occurs. }\end{array}$ & $\begin{array}{l}\text { 1. The location mapping is still } \\
\text { using the figures that are taken } \\
\text { from camera, then adjust with the } \\
\text { regional urban use in the regional } \\
\text { government. } \\
\text { 2. Given data is still through e-mail. }\end{array}$ & $\begin{array}{l}\text { 1. The ability in making decision in } \\
\text { analyzing the construction planning } \\
\text { of the tower in the city spatial } \\
\text { planning. } \\
\text { 2. Regional mapping system that } \\
\text { can ease the process of delivery, } \\
\text { cultivate data information. }\end{array}$ \\
\hline BI & $\begin{array}{l}\text { The ease of doing statistic } \\
\text { towards telecommunication } \\
\text { business for the correct } \\
\text { decision making by the } \\
\text { management of PT. Lintas } \\
\text { Group. }\end{array}$ & $\begin{array}{l}\text { 1. The condition of system and } \\
\text { database infrastructure that is } \\
\text { lacking support in developing } \\
\text { solutions due to the data document } \\
\text { in the development of the } \\
\text { application does not store the file on } \\
\text { the current system. }\end{array}$ & $\begin{array}{l}\text { The availability of system } \\
\text { application, infrastructure, and } \\
\text { database that can be managed for } \\
\text { data dissemination in supporting } \\
\text { the needs of telecommunication } \\
\text { business that can make a decision } \\
\text { in the business process activity of } \\
\text { PT. Lintas Group. }\end{array}$ \\
\hline
\end{tabular}

\section{Recommendation}

Based on the analysis result that has been done to determine what will be given as the guideline for the development of technology and information system to PT. Lintas Group in carrying out the business activity to cover up the weakness and increase the company's competitiveness against the competitors, the recommendation is attached below. 


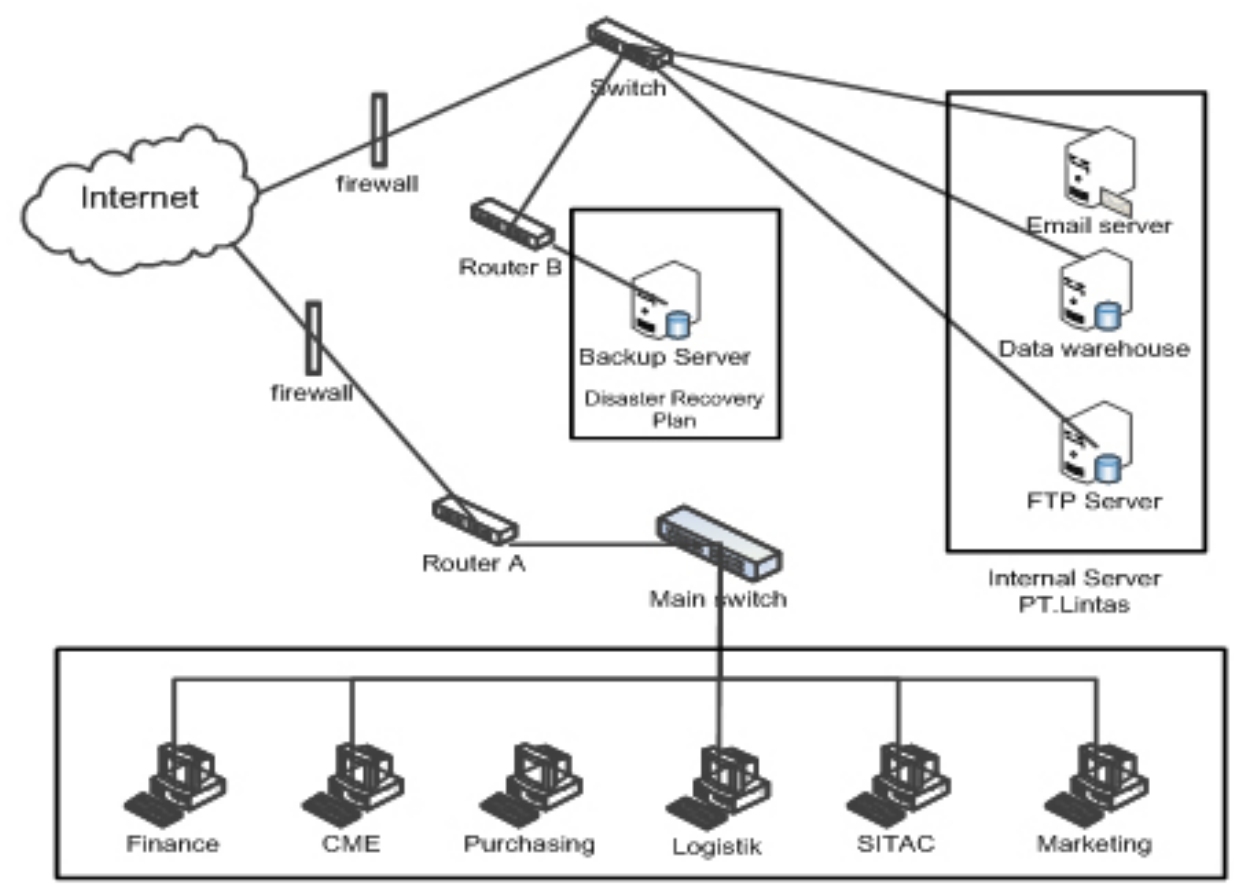

Internal Lan PT.Lintas Group

Fig. 4: Proposal of Network Topology

The solution to increase the employees' performance in making development and utilization planning of IS/IT, it is given a proposal the addition of IT Division (ITPMO and Web Development). The duty of IT PMO is responsible for the projects as well as programs from the early stage to postimplementation. Programs and projects planning within the company ensures the existing IT resources can be empowered in the best way to support the company's strategic initiatives. Web Development is responsible in updating

KMS, SIG and company websites that are based on information and developing the application so that it can work optimally in accordance with the company's needs.

\section{Geographical Information System}

This system is addressed to do data processing and do certain operations by showing and analyzing data, the following is the Web GIS that is going to be developed: (1) The adjustment of the determined users' market. (2) The planning and cultivation of land use. (3) The adjustment and determination of regional coordinate point. (4) Infrastructure arrangement (network, electricity resources, roads, etc.)

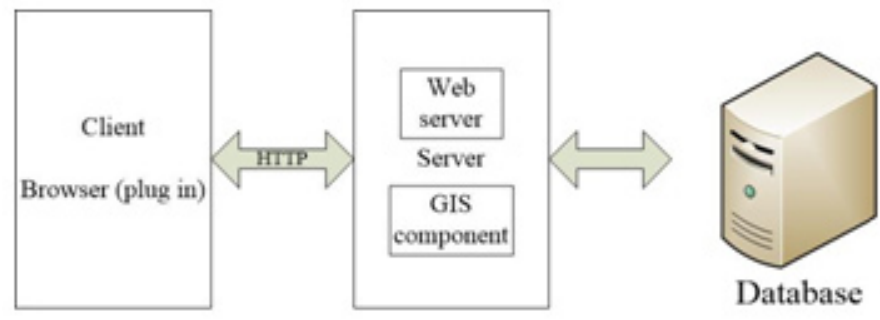

Fig. 5: GIS System Architecture 
Fig. 5 explains about the feature of GIS system design, to be able to communicate with the different components in the web environment, web server is needed.

The Use Case design regarding the provided function by the system of GIS to a user, can be seen in figure 6.

\section{Knowledge Management System}

This system is addressed to increase the ability of company's employees, organizational activities in processing knowledge as an asset. The objective of this KMS is to help staff in learning matters that are related to problems and knowledge information concerning telecommunication, to build KMS. The KMS design that can be done, can be seen in the figure 7 , and figure 8 .

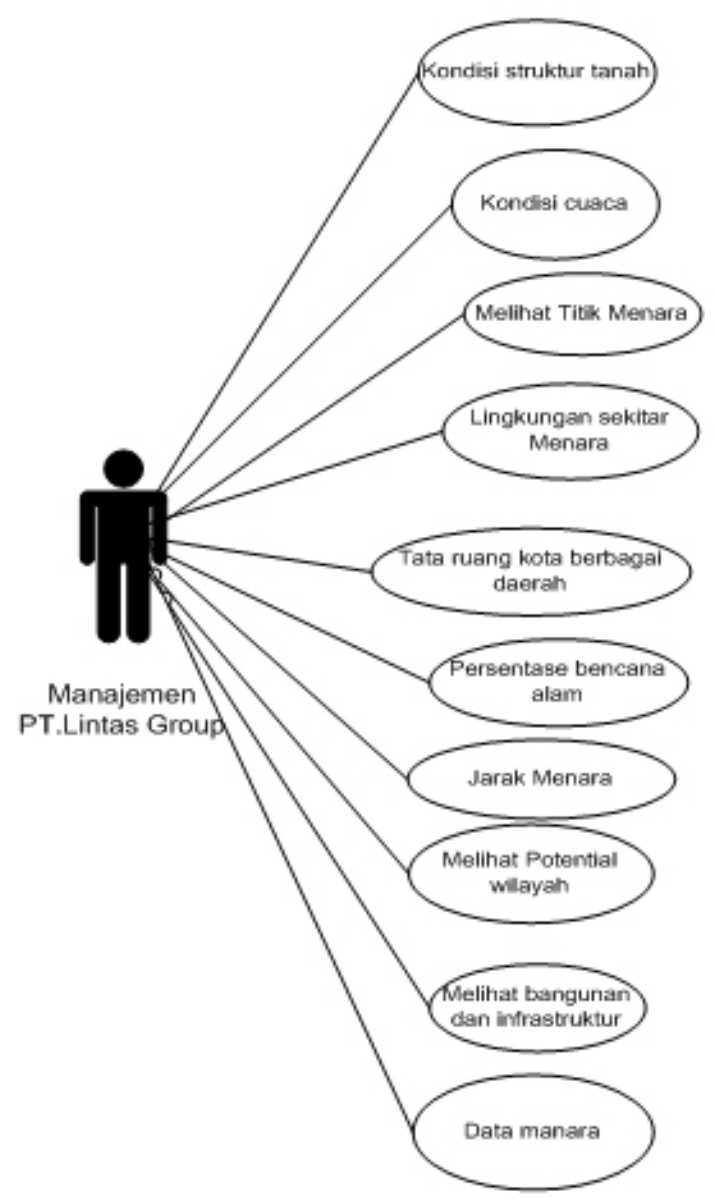

Fig. 6: The Use Case of GIS Diagram

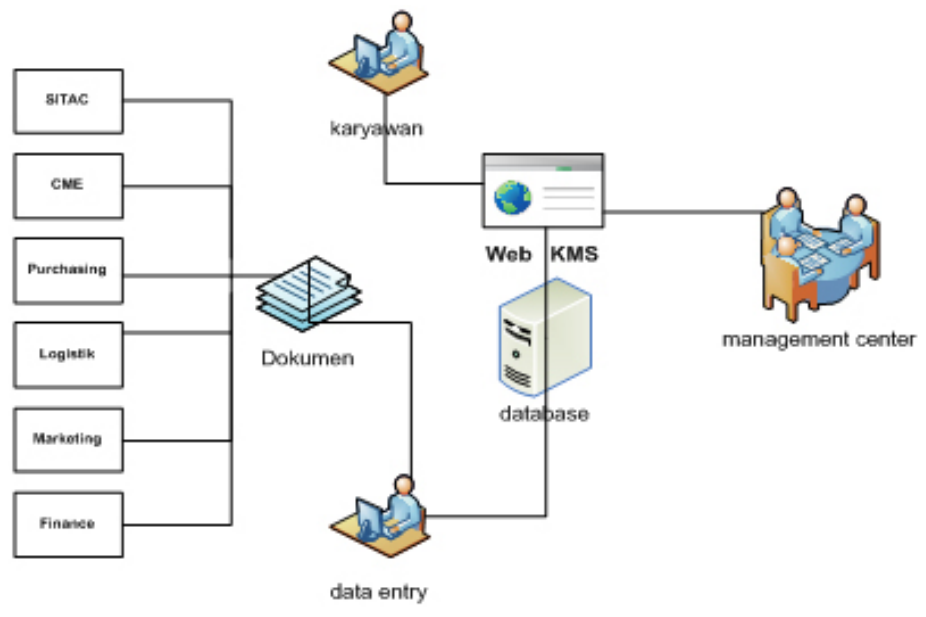

Fig. 7 KMS Architecture 


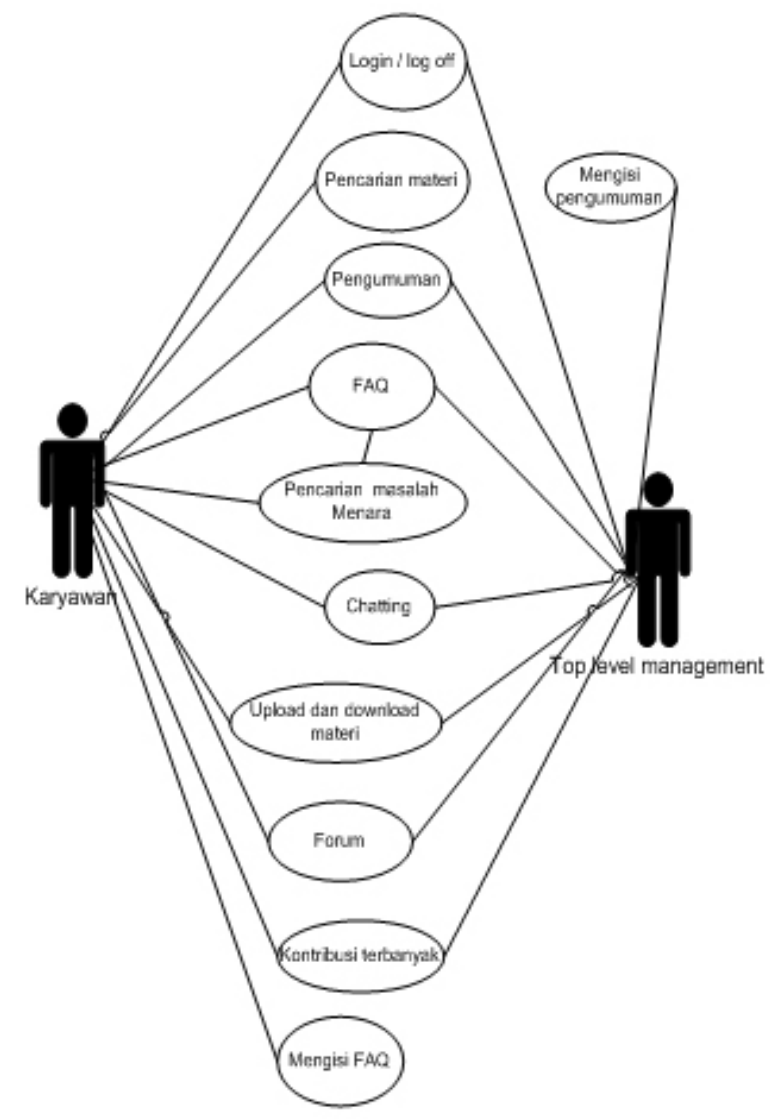

Fig. 8: The Use Case of KMS Diagram

\section{Business Intelligence}

This system is addressed for analysis automation towards data that the company has to support the collection of decision such as the trend of product needs, risks, tower performance, provider determination, the plan of facility maintenance tower, searching for indicators and pattern that affect the tower which are still unknown, and the company's performance. They can be seen in the following figure 9 , and figure 10 .

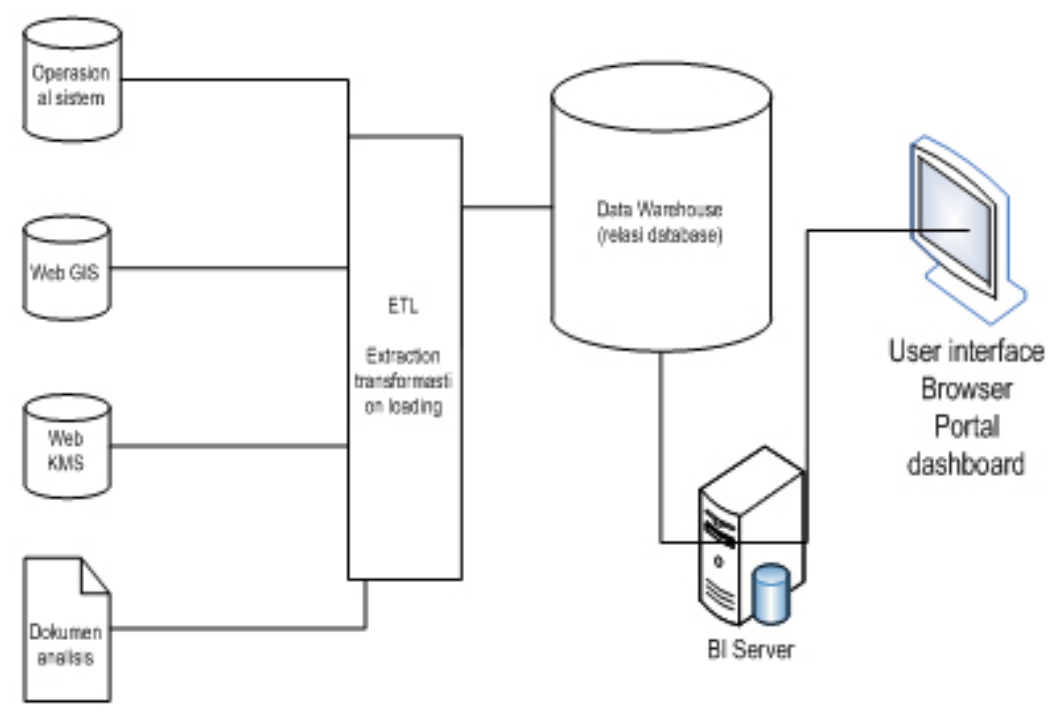

Fig. 9 Business Intelligence Architecture 


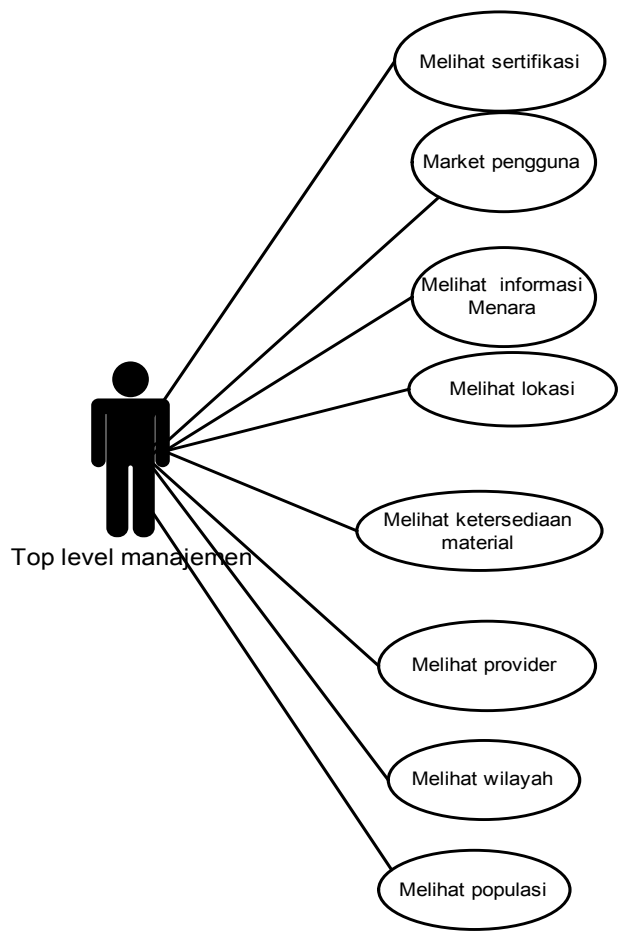

Fig. 10 The Use Case of Business Intelligence Diagram

According to the three proposals of application systems that are addressed from writer to the Management, the company's opinion is really need a system that can fulfill the business activities for the continuation of company in managing the business telecommunication process. Criteria that support the success of system development at PT.Lintas Group are as following:

Table 8 The Criteria for Success Strategy

\begin{tabular}{|c|c|c|}
\hline The success' indicators & Explanation & Status \\
\hline Human Resources & $\begin{array}{l}\text { a. Education and intensive training to increase understanding } \\
\text { concerning about the process flow that will be done into a system } \\
\text { b. Communicative towards the required needs in the difference that } \\
\text { will happen in system development. }\end{array}$ & High \\
\hline Support & $\begin{array}{l}\text { a. Infrastructure with the equipment fulfillment in hardware and } \\
\text { software as well as adequate network in data exchange that can } \\
\text { save and manage company's data as well as provide ability to } \\
\text { analyze data. } \\
\text { b. Documentation in the procedure of system management. }\end{array}$ & High \\
\hline Security & $\begin{array}{l}\text { a. The installation of antivirus and firmware in the side of network } \\
\text { and access usage limitation that is related to information system } \\
\text { that is used, to prevent unwanted things, as well as the usage of } \\
\text { identification card at server room. }\end{array}$ & High \\
\hline Communication & $\begin{array}{l}\text { a. Communication that is involved in giving an opinion, information } \\
\text { exchange concerning the needs that are required in the } \\
\text { development of this system application aims to obtain an intended } \\
\text { result, it is held meeting with the IT Division in order to get the } \\
\text { intended system result at PT. Lintas Group. } \\
\text { b. The realization of integrity towards Divisions concerning an IS/IT } \\
\text { planning. }\end{array}$ & High \\
\hline Flexibility & $\begin{array}{l}\text { a. Upgrade the system that will ease to make changes in accordance } \\
\text { with the needs in the future periods of the business needs of PT. } \\
\text { Cross Group. }\end{array}$ & Moderate \\
\hline
\end{tabular}


According to Table 8, the writer determine the measurement of success based on the observation review at PT. Lintas Group that has been done, within the table of status represents: High (has an important impact to overall activity that is performed), Moderate (the process that has been performed is as a supporter)

\section{CONCLUSION}

This study deduces the following conclusions. By using strategic planning of IS/IT, the company can know the important factors that are needed in developing an information system that is conformable with the company's strategy. The factors can be seen from the analysis result in the form of PEST, ITBSC, and SWOT. The result from PEST analysis shows that there is some threats that obstruct the construction's development of the BTS tower, such as competitors with the latest technology, society, regional regulations however the company can hold out and develop in the meantime. To be able to survive, the company has to build communication with the society and regional government in arranging regional urban land use, so that the process of construction's development of BTS can be carried out without disturbances.

Within SWOT analysis, PT. Lintas Group is in the aggressive position where the strategy that is used by the company can be optimally use to minimize the existing weakness and utilize some several chances to increase business maximally. The estimation of performance by using the method of ITBSC can be seen from some perspectives that are: company's contribution which consists of system development planning, user orientation that is consisted of user's ability in system application, operational improvement is consisted of development evaluation, future orientation is consisted of increasing employees' ability. The result of GAP analysis shows the system that exist in the present time cannot be fulfilled to do business activity, therefore the proposed solution is in the form of system application such as GIS, KMS, and $\mathrm{BI}$.

\section{REFERENCES}

[1] DEPKOMINFO, tentang pedoman pembangunan dan penggunaan bersama menara telekomunikasi, peraturan menteri komunikasi dan informasi republik indonesia no 19/PER/M.KOMINFO/03/2009, http:// www.postel.go.id/?mod=reg\&cid=48\&page $=2$.

[2] Dynastya and H. Sulistyarso, "Model Lokasi Menara BTS ditinjau dari Faktor-faktor penentu lokasi Menara BTS di Surabaya", Jurnal Teknik POMITS, vol. 2, no. 1, 2011, ISSN: 23373539.

[3] W.A. Prijono, "Penataan Menara BTS (Cell Planning)", Jurnal EECCIS, vol. 4, no. 1, 2010.
[4] K. Surendro, "Pemanfaatan Enterprise Architecture Planning Untuk Perencanaan Strategis Sistem Informasi, Jurnal Informatika, vol. 8, no. 1, pp. 1-9, 2007.

[5] A.S. Al-aklabi, and B. A. Al-Allak, "Saudi Telecommunications Company: A Strategy for Sustainable Competitive Advantage", Journal of Advanced Social Research, vol. 1, pp. 76-88, 2011.

[6] W. Scharnhorst, "Life Cycle Assessment in the Telecommunication Industry: A Review. The International Journal of Life Cycle Assessment (OnlineFirst), vol. 12, pp. 1-12, 2006.

[7] J. Peppard, and J. Ward, Strategic planning for information systems, 3rd ed., Chichester, West Sussex, Eng: John Wiley \& Sons, 2002.

[8] R. Saull, S. D. Haes and W. V. Grembergen, Linking the IT Balanced Scorecard to the Business Objectives at a Major Canadian Financial group, 2009. URL: http:/www. antwerpmanagementschool.be/media/287506/ linking $\% 20$ it $\% 20$ scorecard $\% 20$ to $\% 20$ bus $\% 20$ objectives\%20can.pdf 